\title{
Optimum Ratio between Waste Cooking Oil and Coconut Oil as Raw Material for Biodiesel Production
}

\author{
Muthia Elma", Satria Anugerah Suhendra ${ }^{\#}$, Wahyuddin", Wido Saputri ${ }^{\#}$, Shafira Ainun Adhi Utami ${ }^{\#}$

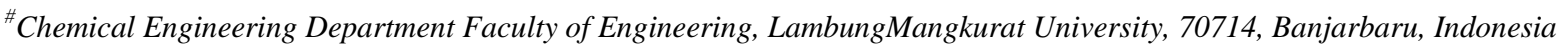 \\ E-mail: melma@unlam.ac.id
}

\begin{abstract}
Biodiesel is an energy that is processed from biological processes and employ agriculture products rather than geological processes. Waste Cooking Oil (WCO) and Coconut Oil (CO) are some of the agriculture products that have been applied for this work. The utilization of WCO enables to cycle the waste from the environment and also CO may promote local home industries. The aims of this work are to produce biodiesel from a mixture of waste cooking oil and coconut oil. This work is also to study the optimum composition between these two materials $(0 \%$ to $100 \%$ WCO or CO in reverse) in producing biodiesel. Several methods were applied in this work: i.e. esterification, transesterification, washing, drying and filtering processes. Some steps of characterization were conducted to fulfil the International Standard (EN 14214). The yield of biodiesel produced was $97.65 \%$ with oil mixture composition of50\% WCO and50\% CO. The FAME component in 50\% WCO and 50\% CO showed as the nonanoic acid methyl ester $\left(\mathrm{C}_{15} \mathrm{H}_{20} \mathrm{O}_{2}\right)$ with the composition of $37,79 \%$.
\end{abstract}

Keywords - biodiesel; esterification; transesterification; waste cooking oil; coconut oil

\section{INTRODUCTION}

Energy is one of the most important commodities in the universe. Energy is consumed by many crucial elements to generate electricity [1]-[3] for light, trains, cars, planes, homes, offices, factories, farms, school, and much more. It is also a fundamental element to do work and to ease people's daily lives.

Energy is divided into two categories; unrenewable and renewable energy. Nowadays, fossils energy is a big issue in the world due to uncontrolled human exploitation. Therefore, the deposit becomes limited and even no longer exist. Many countries use fossil energy as their energy sources, however, other countries have been applying renewable energy for their lives lately, i.e. biodiesel. This energy source is from low carbon sources and eco-friendly for green technology and an alternative way to replace the dependence on fossil fuel. As formerly known, the massive problem caused by fossil fuel is pollution. It is necessary to develop the highenergy demand by improving the existence of renewable energy with lower environmental impact.

Biodiesel is an alternative and potential energy. It consists of ester (methyl ester or ethyl ester) compound. This compound is non-toxic, very economic and renewable. Generally, biodiesel is made from vegetable oil and animal fats which come from agricultural sector compared to diesel fuel production from geological processes.
Waste cooking oil (WCO) is the residual oil commonly obtained from the restaurant and/or household cooking. It can be considered as a waste and it is usually discharged directly to the environment. It contains a lot of free fatty acid [4] and free radical substances that potentially harmful for health and environment. The content of free fatty acids can be reduced by esterification with the help of homogeneous acid catalysts such as sulfuric acid [5] or heterogeneous acid catalyst like zeolite [6] or acid activated clay [7].

Coconut oil as raw material to produce biodiesel is not common especially people who live in developing countries. It is due to the coconut oil prefer to use as cooking oil or another food product other than biofuel. On the other hand, application of biodiesel in engine performance shows very low engine emission. It reduces $\sim 75 \%$ smoke, $\sim 40 \% \mathrm{NO}_{\mathrm{x}}$ and $\sim 15 \% \quad \mathrm{CO}_{2}$ [8] if $100 \%$ coconut oil is used as raw material. Although coconut oil would provide low emission, however, it possibly led to more labour and extra transport cost for export. Due to that, by mixing waste cooking oil and coconut oil would give more economical and information about biodiesel production.

This work aims to recycle waste cooking oil discharged to the environment and coconut oil as raw material to produce biodiesel. This is important to sustain the environmental values and to suit local home industries. Experiments were carried out by collecting waste cooking oil from a local restaurant in Banjarbaru, South Kalimantan, Indonesia. 
Furthermore, coconut oil was then collected from home industry in Kotabaru, South Kalimantan, Indonesia. At the end, the yield of biodiesel will be calculated to estimates the performance of biodiesel.

\section{MATERIAL AND METHOD}

\section{A. Material}

During this work, waste cooking oil (WCO) was collected from some local restaurants in Banjarbaru, South Kalimantan, Indonesia, coconut oil (CO) was then collected from home industry in Kotabaru, South Kalimantan, Indonesia. The other chemical used are; Methanol (Merck), $\mathrm{H}_{2} \mathrm{SO}_{4}$ (Merck), PHPT, indicator, chloroform (Merck), KOH (Merck), Sartorius quantitative grade 393 filter papers, ZnO, $\mathrm{HCl}$ (Merck). The ratio of oil mixtures as a raw material in biodiesel production is listed in Table 1 .

TABLE I

COMPARISON OF OIL MIXTURES

\begin{tabular}{|l|l|l|l|l|l|}
\hline \multicolumn{1}{|c|}{ Vegetable oil } & \multicolumn{5}{c|}{ Ratio (\%) } \\
\hline Coconut oil & 0 & 25 & 50 & 75 & 100 \\
\hline Waste cooking oil & 100 & 75 & 50 & 25 & 0 \\
\hline
\end{tabular}

\section{B. Method}

There are six steps pointed out during this work, such as; (i) pretreatment process, (ii) esterification process, (iii) transesterification process, (iv) purification process, (v) biodiesel analysis.

1) Pretreatment Process: $200 \mathrm{~mL}$ mixtures of waste cooking oil and coconut oil are mixed homogeneously. The ratio of waste cooking oil and coconut oil are respectively: $100: 0 ; 75: 25 ; 50: 50 ; 25: 75$ and $0: 100$. Then, the composition of FFA contents was measured by adding 3 grams of the oil mixtures into $50 \mathrm{~mL}$ of ethanol $95 \%$. They were titrated using KOH-ethanol 0,1085 $\mathrm{N}$ by adding five drops of phpt indicator to determine whether the sample is acidic or basic. This titration is stopped after the solution turned pink.

2) Esterification Process: Oil mixtures (WCO \& CO) were mixed together with methanol and acid catalyst $\left(\mathrm{H}_{2} \mathrm{SO}_{4}\right)$ to perform the esterification process. The volume of waste cooking oil and coconut oil mixture was $200 \mathrm{~mL}$ and the catalyst used was $0.5 \%$ from the volume of oil mixtures. For 100:0 composition oil mixtures, the amount of methanol used was $38 \%$ and $30 \%$ for $75: 25$. Oil mixtures, methanol, and catalyst were then poured inside three-neck flask and magnetic stirrer to help to dilute solution. The reaction was then performed and kept constant at a temperature of $65^{\circ} \mathrm{C}$, 400rpm. The reaction was conducted for 90 minutes for 100:0, and 60 minutes for 75:25. The next process after the reaction was decantation that used separator funnel and lasted for 60 minutes. A 3-g sample was prepared to investigate FFA. After 60 minutes, the oil was separated from the glycerol of separator funnel. Phase separation between the top and middle (phospholipid) phase volumes were measured. More information about the esterification reaction can be seen in Table 2 .
TABLE II

OIL Mixtures TREATMENT FOR ESTERIFICATION PROCESS

\begin{tabular}{|c|c|c|}
\hline $\begin{array}{c}\text { Oil mixtures } \\
(\text { WCO vs CO) }\end{array}$ & $\begin{array}{c}\text { Methanol } \\
(\boldsymbol{\%} \mathbf{v} / \mathbf{v})\end{array}$ & $\begin{array}{c}\text { Reaction Time } \\
\text { (Minute) }\end{array}$ \\
\hline $50: 50$ & 28 & 60 \\
\hline $25: 75$ & 19 & 60 \\
\hline
\end{tabular}

3) Trans-esterification Process: Trans-esterification process was carried out at a temperature of $65^{\circ} \mathrm{C}, 400 \mathrm{rpm}$. The total volume of oil mixtures was $200 \mathrm{~mL}$. The amount of methanol added was varied (see Table 3). The amount of $\mathrm{KOH}$-methanol taken was $75 \%$ of total $200 \mathrm{~mL}$ and they were poured into a three-neck flask. They were then stirred using magnetic stirrer for a set of time. The mixtures were decanted to separate between methyl ester and glycerol. After decantation process, $25 \%$ of $\mathrm{KOH}$-methanol from step 1 was added to methyl ester and both compounds along with a magnetic stirrer were inserted to a three-neck flask. The mixture was heated and stirred at $65^{\circ} \mathrm{C}, 400 \mathrm{rpm}$. Then, the mixtures were decanted for another 15 minutes.

TABLE III

OIL MiXTURes AND CHEMICAL RATIOS FOR TRANSESTERIFICATION REACTION

\begin{tabular}{|c|c|c|c|}
\hline $\begin{array}{c}\text { Oil mixtures } \\
\text { (WCO vs } \\
\text { CO) }\end{array}$ & $\begin{array}{c}\text { Methanol } \\
(\% \mathbf{\%} / \mathbf{v})\end{array}$ & $\begin{array}{c}\text { KOH } \\
\text { composition } \\
(\% \mathbf{\%} / \mathbf{v})\end{array}$ & $\begin{array}{c}\text { Reaction } \\
\text { time } \\
\text { (minute) }\end{array}$ \\
\hline \multirow{3}{*}{$100: 0$} & 23 & 0,9 & 60 \\
\cline { 2 - 4 } & 20 & 0,9 & 60 \\
\cline { 2 - 4 } & 18 & 0,9 & 60 \\
\cline { 2 - 4 } & 23 & 0,9 & 60 \\
\cline { 2 - 4 } & 20 & 0,9 & 60 \\
\hline \multirow{3}{*}{$75: 25$} & 21 & 0,9 & 60 \\
\cline { 2 - 4 } & 25 & 0,9 & 80 \\
\hline \multirow{2}{*}{$50: 50$} & 19 & 0,9 & 70 \\
\hline \multirow{2}{*}{$25: 75$} & 19 & 0,9 & 40 \\
\hline $0: 100$ & 19 & 0,9 & 50 \\
\hline
\end{tabular}

4) Purification Process: The purification process for this work consisted of the washing and drying process. Methyl ester on top of the solution was separated from glycerol on the bottom. A $20 \mathrm{~mL}$ volume of hot distilled water at $60^{\circ} \mathrm{C}$ was poured into the separator funnel. The solution was then shaken and decanted for 1 minute so that the two phases separation easily separated and measured. This work was repeated until the color of solutions at the bottom has changed from yellowish to clear $(\mathrm{pH}=6)$.

The process that continued with drying process for the sample with the ratio of 75:25 of WCO:CO mixture. The oil containing methyl ester was heated to $150^{\circ} \mathrm{C}$ for 20 minutes with agitation of $300 \mathrm{rpm}$. This method has been used in order to evaporate water content in the solution. The solution was then refrigerated for 1,5 hours. It was then filtered using butcher funnel and membrane vacuum pump. Then, the oil resulted as biodiesel product was stored. The similar procedures were also conducted to another ratio of oil mixtures. 
5) Biodiesel Analysis: Several analyses have been conducted to observe the biodiesel production, such as total glycerol, acid value, saponification value, composition using $\mathrm{GC} / \mathrm{MS}$, and analysis of water content.

\section{RESULTS AND DISCUSSION}

Waste cooking Oil (WCO) used in this work was a waste palm oil that is physically appeared in dark brown. It is due to the impurities contained in the WCO. In order to separate the impurities, WCO was settling down for $\sim 3$ months at room temperature $\left(\sim 25^{\circ} \mathrm{C}\right)$. It is aimed to decrease FFA content of WCO [9]. After settling down, the FFA content was measured in order to know the FFA value before esterification process. Fig. 1 shows the FFA content of each ratio of $\mathrm{WCO}$ and $\mathrm{CO}$.

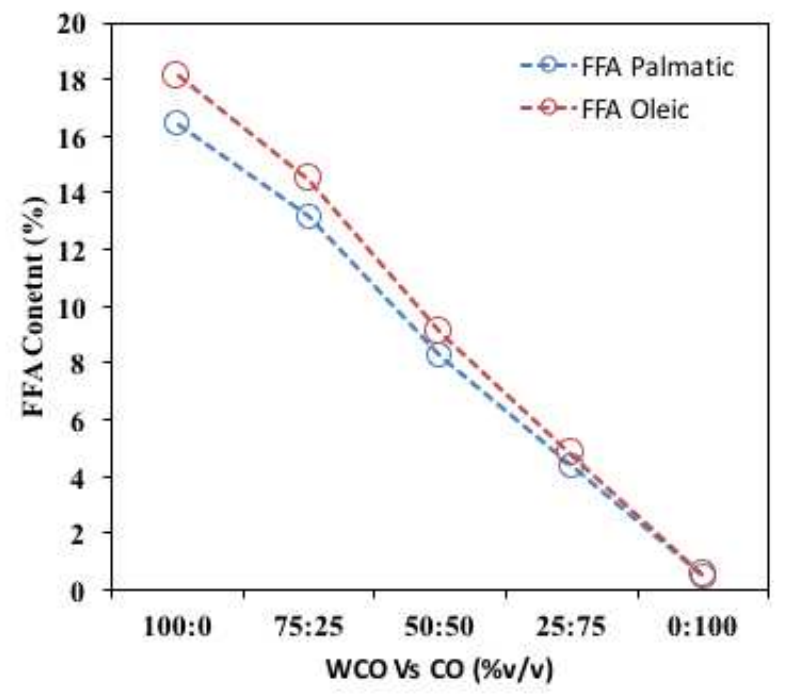

Fig. 1 FFA content WCO vs CO

The highest content of FFA (16-18\%) from Fig. 1 shows that the highest content of WCO (pure WCO). On the other hand, the lowest FFA content $(1.2 \%)$ was pure CO. It is a confirmation that pure $\mathrm{WCO}$ has the highest impurities due to this oil was used for cooking. So, the impurities come from the residue of material left over or decompose during usage. In addition, when WCO is directly used in the transesterification process without esterification process in advance cause the saponification process as a result of reaction with the free fatty acid or alkaline base catalyst inhibit the formation of methyl ester [10].

In Fig. 1, it shows that the FFA content of oleic is greater than the FFA palmitic for WCO. It is found that the higher the content of FFA oleic obtained, more unsaturated fat content in an oil sample existed. Oleic acid is an acid that can be converted into the polyester by adding methanol, which has the same carbon chain structure as petroleum. The process is conducted to change the oleic acid into the polyester through the esterification process. According to Reference [11], the dominant content of unsaturated fatty acid in the waste cooking oil is palmitic acid, while the dominant unsaturated fatty acid in waste cooking oil is oleic acid. So, the content of palmitic and oleic acid are important parameters in analysing FFA content of oil mixtures.
Moreover, palmitic acid and oleic acid are more dominant in palm oil [12]. The variations of palmitic and oleic contents in oil have an effect to the cetane number of biodiesel. An addition of $6 \%$ Palmitic acid in a biodiesel may increase the cetane number to $29.30 \%$ [13]. Thus FFA content in this work is generated from the calculation of oleic FFA content. It may affect to cetane number and the composition of FAME. The main components of methyl ester formed are palmitic and oleic. It is a combination of saturated and unsaturated fatty acid. The cetane number of oil is affected by a number of saturated compounds in the oil. It is getting higher by a large amount of saturated fat in FAME. Otherwise, the $\mathrm{CN}$ may be reduced with the increase of the number of carbon [14].

1) Esterification of Waste Cooking Oil and Coconut Oil: The aim of the esterification process is to decrease the FFA content from oil mixtures. Sulfuric acid is formerly known as a cheap and widely used acid catalyst for esterification process. Sulfuric acid is able to reduce the FFA content in the oil mixtures from $20 \%$ to less than $2 \%$ in one hour $(60$ minutes). The optimum temperature of esterification reaction was set $65^{\circ} \mathrm{C}$. At this temperature, FFA content reduced from $23.2 \%$ to $2 \%$ while the conversion of FFA to FAME was increased to $93.87 \%$. The conversion of FFA to FAME decreased with the increase of reaction temperature. If the reaction temperature is ranged from $60^{\circ} \mathrm{C}-65^{\circ} \mathrm{C}$, the FFA will decrease up to $1 \%$. Thus, it will increase the FFA to FAME conversion as well. In this study, the process of catalyst mixing with oil was conducted at a speed of 400rpm. As the conversion of FFA to FAME reached to $94 \%$, so, the conversion of FFA to FAME may become lower if the speed exceeds 400rpm [15].

The variation in methanol ratio was set in order to determine the effective conversion from raw materials to biodiesel. The reaction occurred during the esterification process, as follow:

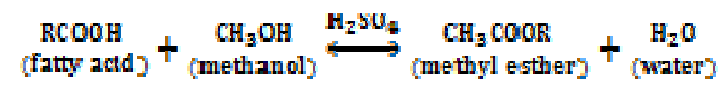

The esterification reaction is a reversible process; thus, methanol should be used excessively in order to push the reaction towards ester as the main product. In this work, a variation of oil mixtures correlates between the FFA, the effective time and the effectiveness of the methanol as a solvent. The greater the composition of waste cooking oil in a sample, the larger the amount of methanol used. This is due to the high content of FFAof WCO. The high content of FFA was influenced by the oil and water hydrolysis as well as the high temperature of heating. The following Fig. 2 is the FFA content before and after esterification process.

As performed in Fig. 2, the FFA content decreases sharply before esterification process occurred. The higher ratio of the waste cooking oil, the greater the FFA content detected. Waste cooking oil (WCO) is an oxidized oil with a high peroxide number thus when mixed with fresh oil (coconut oil). It may cause an increase in peroxide value of the mixture. The high number of peroxide can also affect the rancidity of mixtures [16]. The ratio WCO-CO mixture (50:50) has the lowest FFA content after esterification process. It is due to coconut oil contains more stable 
unsaturated fat, even after being stored for one year at room temperature. It commonly does not change to rancid even though it contained $9 \%$ of saturated fatty acid. Coconut oil with low contents of oleic and palmitic acid are able to reduce FFA of waste cooking oil. The average of FFA reduction is $94 \%$. This condition is in accordance with previous studies stated that if the velocity is set at 400rpm, the conversion from FFA to FAME will be $94 \%$ [12].

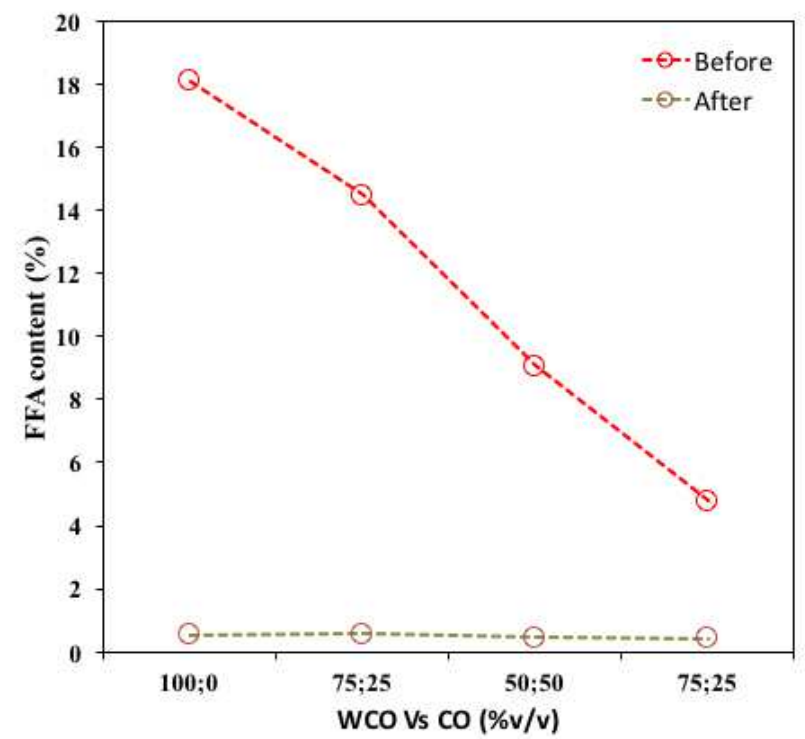

Fig. 2 FFA content WCO vs $\mathrm{CO}$ before and after esterification process

Decantation process was conducted to form a water molecule and impurities fell to the bottom (base layer) of the separator funnel while methyl ester was on the top layer. This is because the density of water and impurities are higher than the oil density (methyl ester). Moreover, esterification process can lower FFA as well as impurities and water content in raw materials. The following Fig. 3 shows the relation of oil mixtures composition and waterimpurities.

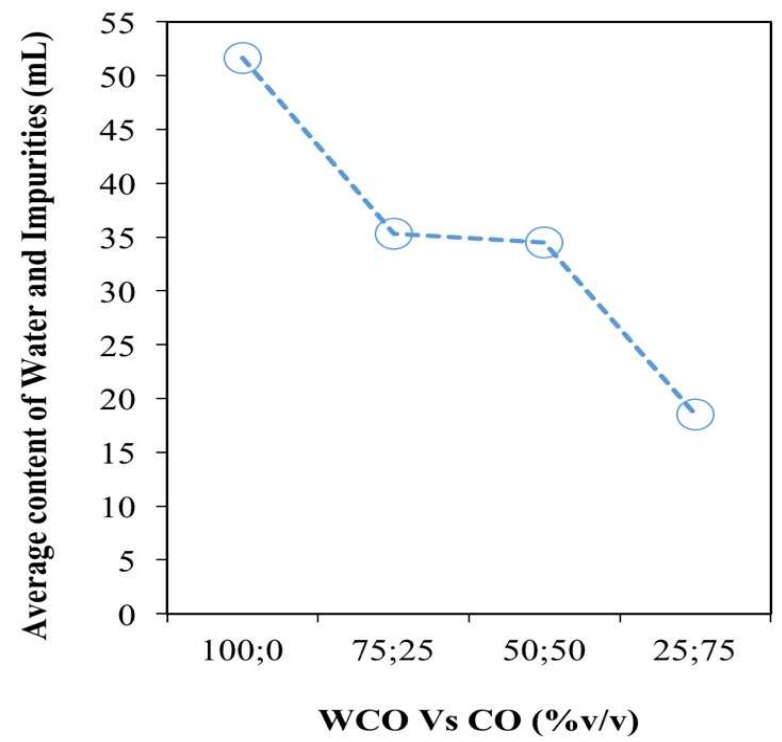

Fig.. 3 The relationship between the average content of water and impurities and mixed oil composition
Fig. 3 shows the lower the amount of waste cooking oil in the oil mixtures composition. The water content and impurities will be influenced by the nature of rancidity and oxidation of the waste cooking oil. If the waste cooking oil is mixed with coconut oil in a certain composition, then the impurities and water results obtained over time will be reduced and the methyl ester obtained will increase. In addition, the decantation time is also influential in the increase of impurities and water content of the product of methyl ester. The longer the time for decantation, the greater the impurities and water obtained. Since the nature of the sulphuric acid catalyst is hygroscopic, the water will be absorbed by the sulfuric acid and the production of biodiesel as main products will increase.

As seen in equation 1, the main product of esterification resulted is methyl ester. This compound will be used as raw material for the trans-esterification process. In order to meet the standard of biodiesel product, the FFA content should meet EN14214. Table 4 shows the standard method of biodiesel based on international standard. If compare to FFA content in Fig. 2, FFA content after esterification must be below $1 \%$.

2) Transesterification Process: Trans-esterification is a reaction where triglyceride, diglyceride, and mono glyceride formed and converted into glycerol [5]. In this study, the trans-esterification process employs methanol and $\mathrm{KOH}$ as a base catalyst. According to Reference [17], base catalyst i.e. $\mathrm{KOH}$ is a type of catalyst which very sensitive to FFA content. $\mathrm{KOH}$ catalyst is used to purify the product. Then, methanol acts as the organic solution. During the chemical reaction, methanol should have an accurate $\mathrm{pH}$ level, ideal density, low boiling point, and being controlled. The transesterification reaction of this process is shown in equation (2).

From equation (1), it is clearly shown that the reaction is a reversible reaction, wherein methyl ester and glycerol is formed at the end of the reaction as a product. In this study, the trans-esterification reaction occurred in two steps of the process with variations of methanol concentration. The purpose of this variation is to find the composition which results in the optimum yield. The variation of time is set to determine the optimum time for the transesterification process. The addition of $0.9 \% \mathrm{KOH}$ catalyst in the study is conducted in order to obtain optimum yield during a transesterification process $(0.9 \%-1 \%)$ for palm oil [18].

The optimum temperature for the trans-esterification reaction was $65^{\circ} \mathrm{C}$. If it reached more than $65^{\circ} \mathrm{C}$ (boiling point of methanol), then it will accelerate the saponification of glycerol before methanolysis reaction occurred [19]. This condition is due to the presence of base catalyst. 


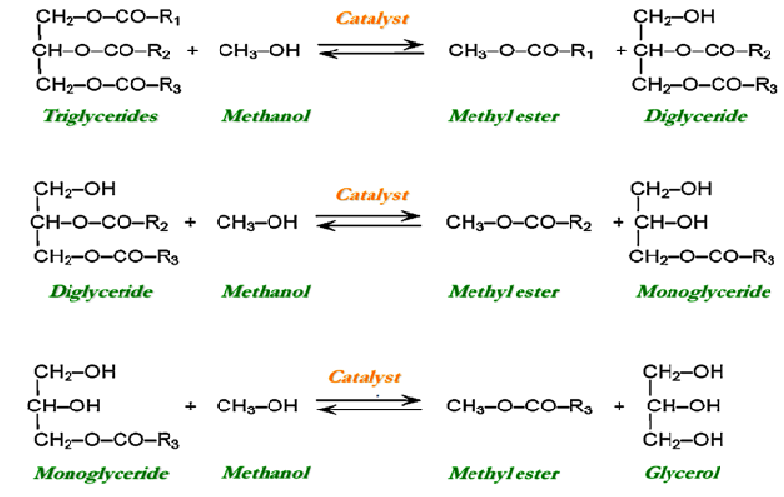

TABLE IV

PARAMETER TEST METHODS INTERNATIONAL STANDARD

\begin{tabular}{|c|c|c|c|c|}
\hline Parameter & Unit & Min & Max & Test Method \\
\hline $\begin{array}{l}\text { Sulphated ash } \\
\text { content }\end{array}$ & $\%(\mathrm{w})$ & - & 0.02 & ISO 3987 \\
\hline Water content & $\mathrm{mg} / \mathrm{Kg}$ & - & 500 & EN ISO 12937 \\
\hline $\begin{array}{l}\text { Total } \\
\text { contamination }\end{array}$ & $\mathrm{mg} / \mathrm{Kg}$ & - & 24 & EN 12662 \\
\hline $\begin{array}{l}\text { Copper Strip } \\
\text { Corrosion }(3 \mathrm{hr} \text { at } \\
\left.50^{\circ} \mathrm{C}\right)\end{array}$ & Rating & Class 1 & Class 1 & EN ISO 2160 \\
\hline Thermal stability & - & - & - & - \\
\hline $\begin{array}{l}\text { Oxidation } \\
\text { stability, } 110^{\circ} \mathrm{C}\end{array}$ & hours & 6 & & pr EN 14112 \\
\hline Acid value & $\mathrm{mg} \mathrm{KOH} / \mathrm{g}$ & - & 0.5 & pr EN 14104 \\
\hline Iodine value & - & - & 120 & pr EN 14111 \\
\hline $\begin{array}{l}\text { Linolenic acid } \\
\text { methyl ester }\end{array}$ & $\%(\mathrm{w})$ & - & 12 & pr EN 14103 \\
\hline $\begin{array}{l}\text { Polyunsaturated } \\
\text { ( } \geq 4 \text { double } \\
\text { bonds) methyl } \\
\text { esters }\end{array}$ & $\%(\mathrm{w})$ & - & 1 & - \\
\hline Methanol content & $\%(\mathrm{w})$ & - & 0.2 & pr EN 14110 \\
\hline $\begin{array}{l}\text { Monoglyceride } \\
\text { content }\end{array}$ & $\%(\mathrm{w})$ & - & 0.8 & pr EN 14105 \\
\hline $\begin{array}{l}\text { Diglyceride } \\
\text { Content }\end{array}$ & $\%(\mathrm{w})$ & - & 0.2 & pr EN 14105 \\
\hline $\begin{array}{l}\text { Triglyceride } \\
\text { Content }\end{array}$ & $\%(\mathrm{w})$ & - & 0.2 & pr EN 14105 \\
\hline Free Gylcerol & $\%(\mathrm{w})$ & - & 0.02 & $\begin{array}{l}\text { pr EN } 14105 \\
\text { pr EN } 14106 \\
\end{array}$ \\
\hline $\begin{array}{l}\text { Alkaline Metals } \\
(\mathrm{Na}+\mathrm{K})\end{array}$ & $\mathrm{mg} / \mathrm{Kg}$ & - & 5 & $\begin{array}{l}\text { pr EN } 14108 \\
\text { pr EN } 14109\end{array}$ \\
\hline $\begin{array}{l}\text { Phosphorus } \\
\text { Content }\end{array}$ & $\mathrm{mg} / \mathrm{Kg}$ & - & 10 & pr EN 14107 \\
\hline
\end{tabular}

In Fig. 4, it performed the visualization of biodiesel production steps from esterification process. The impurities at bottom layer were found as seen in Fig. 4(a). The process was continued to be trans-esterification as shown in Fig. 4(b). From this stage, the impurities were suddenly decreased. It means that the reaction was continued to produce methyl ester. As shown in Fig. 4(c), the biodiesel product still consisted of water. It is due to washing process to separate between methyl ester and water. In Fig. 4(d), methyl ester formed when the water content was evaporated during the drying process.

Trans-esterification reaction in this research was conducted in two steps. The first step was a pretreatment to convert FFA from esterification into oil (biodiesel). The second step was to optimize the catalyst so that the remaining FFA content in the reaction can be converted to increase yield more than $90 \%$ [19]. As mentioned previously, the amount of methanol- $\mathrm{KOH}$ that was added in the first step was $75 \%$ from $200 \mathrm{~mL}$, while in the $2^{\text {nd }}$ step, $\mathrm{KOH}$-methanol that was added was $25 \%$ of total $200 \mathrm{~mL}$. In the first stage of the transesterification reaction, the glycerol obtained was greater than the second stage (76-96\%). By applying the second step, the less glycerol was produced (4-23\%). So, the two steps of process enhanced the chemical reaction with support by acid and base catalyst.

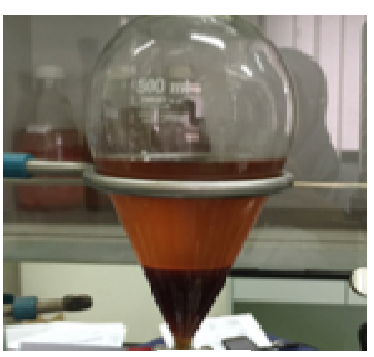

(a)

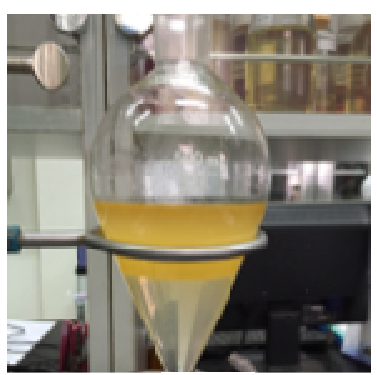

(c)

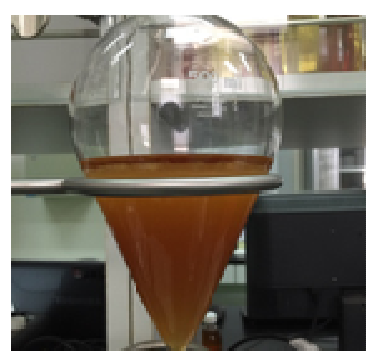

(b)

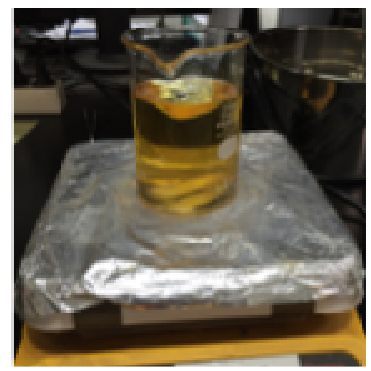

(d)
Fig. 4 Biodiesel Processes (a) esterification, (b) transesterification, (c) washing, and (d) drying process of $50 \mathrm{WCO}: 50 \mathrm{CO}$ at $65^{\circ} \mathrm{C}, 60$ minutes, and $400 \mathrm{rpm}$.

3) Purification of Biodiesel: Purification of methyl ester (biodiesel) after the transesterification reaction is conducted in order to eliminate water content and glycerol remaining in the methyl ester solution. The washing process was conducted at $60^{\circ} \mathrm{C}$, the temperature is set below methanol boiling point as to accelerate the reaction. The process of settling down in biodiesel purification is to remove free glycerol that still mixed with methyl ester. Drying process help to remove the moisture content. By continuing with final purification process, it will produce pure biodiesel.

The yield of biodiesel was calculated to know the quality of biodiesel as a product. The yield obtained from all the biodiesel processes is performed in Fig.5. Production steps using WCO-CO oil mixture with the ratio of 50:50 shows the highest yield. Methanol as a solvent gave the influence to increase the product yield. Due to the transesterification reaction is reversible, less methanol used led to a higher yield as well as reaction time. The yield of biodiesel was increased with the increase of reaction time and less methanol [20]. 


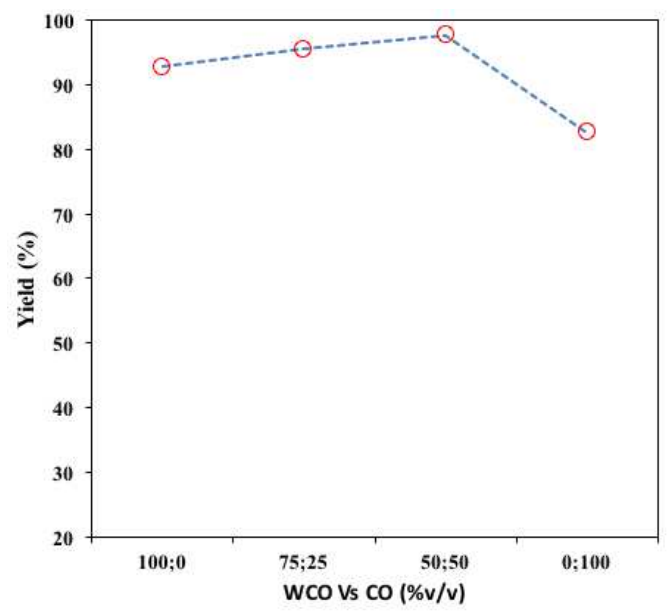

Fig. 5 Yield of biodiesel as product

4) Analysis of Biodiesel: Several analyses have been done to validate the quality of biodiesel product. Based on Fig. 5, the composition percentage of mixture of WCO:CO (50:50) was performing the highest yield. Afterward, the quality test conducted for this ratio can be seen in Table 5 . From data shown in Table 5, it can be observed that the biodiesel quality of 50WCO:50CO mixtures is in compliance with EN14214 standards.

TABLE V

BIODIESEL QUALITY TEST COMPARE TO STANDARD EN 14214

\begin{tabular}{|c|l|l|c|}
\hline No. & \multicolumn{1}{|c|}{ Parameter } & $\begin{array}{c}\text { EN-14214 } \\
\text { Standard }\end{array}$ & $\begin{array}{c}\text { Biodiesel } \\
\text { (50WCO : 50CO) }\end{array}$ \\
\hline 1 & Total Glycerol (\%-w) & Max. 0,25 & 0,23 \\
\hline 2 & $\begin{array}{l}\text { Acid Value(mg } \\
\text { KOH/g) }\end{array}$ & Max. 0,5 & 0,12 \\
\hline 3 & Saponification Value & Max. 230 & 225.13 \\
\hline 4 & Water Content (ppm) & Max.500 & 0,56 \\
\hline 5 & Ester Content (\%-w) & Min. 96,5 & 97,81 \\
\hline
\end{tabular}

5) Analysis of GC/MS: Analysis of GC/MS is used to analyse the chemical composition in biodiesel synthesis. There is a peak in the analysis of GC/MS and each peak will respond to FAME, the graphic will then be analysed based on library match software (NO. NIST and WILEY229). FAME identification varied from experimental data and compared to the range of time data received from the mass spectrometric analysis. In this study, the biodiesel product from raw materials WCO-CO with a mixture ratio of 50\%:50\% was analysed using GC/MS as seen in Fig. 6.

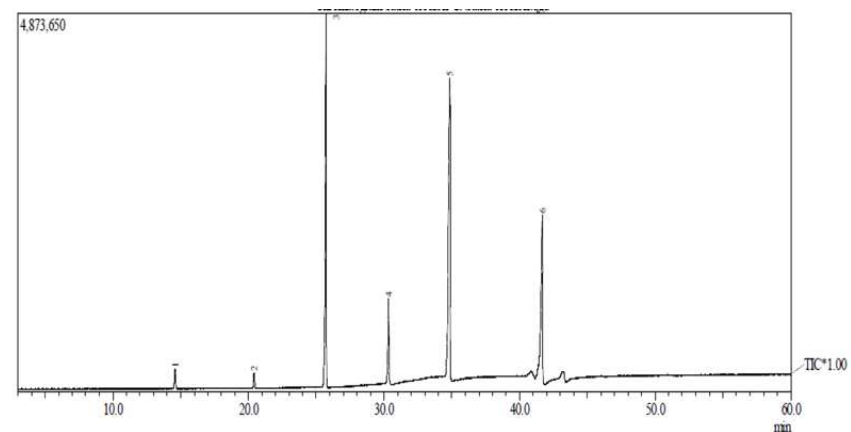

Fig. 6 Analysis of GC/MS of 50WCO:50CO Biodieselas product

In Fig.6, it can be seen that there are six major peaks. These peaks indicate the amount of biodiesel content went through the process of separation from its components by changing the compound sample into ions that move and can be separated. Below is the data of FAME content in biodiesel. The identification of six main compounds in biodiesel produces (case of mixture ratio 50:50) was performed in Table 6 . It is shown that the most dominant compound in the product is nonanoic acid, methyl ester $\left(\mathrm{C}_{10} \mathrm{H}_{20} \mathrm{O}_{2}\right)$ with a content value of $37.79 \%$. On the second value is dodecanoic acid, methyl ester of $31.85 \%$. Overall, the majority of methyl ester is saturated fatty acids (such as $\mathrm{C}_{9} \mathrm{H}_{18} \mathrm{O}_{2}, \mathrm{C}_{11} \mathrm{H}_{22} \mathrm{O}_{2}, \mathrm{C}_{13} \mathrm{H}_{26} \mathrm{O}_{2}, \mathrm{C}_{15} \mathrm{H}_{30} \mathrm{O}_{2}, \mathrm{C}_{10} \mathrm{H}_{20} \mathrm{O}_{2}$ ) and the rest is cyclopropanedo decanoic acid, 2-octyl-, methyl ester $\left(\mathrm{C}_{24} \mathrm{H}_{46} \mathrm{O}_{2}\right)$.

TABLE VI

FAME BIODIESEL CONTENT OF 50WCO: $50 \mathrm{CO}$

\begin{tabular}{|c|l|c|c|c|}
\hline $\begin{array}{c}\text { No. } \\
\text { Peak }\end{array}$ & \multicolumn{1}{|c|}{ Component } & Formula & $\begin{array}{c}\text { Content } \\
(\mathbf{\%})\end{array}$ & $\begin{array}{c}\text { R.Time } \\
\text { (Min) }\end{array}$ \\
\hline 1 & $\begin{array}{l}\text { Octanoic acid, } \\
\text { methyl ester }\end{array}$ & $\mathrm{C}_{9} \mathrm{H}_{18} \mathrm{O}_{2}$ & 1,42 & 14,586 \\
\hline 2 & $\begin{array}{l}\text { Decanoic acid, } \\
\text { methyl ester }\end{array}$ & $\mathrm{C}_{11} \mathrm{H}_{22} \mathrm{O}_{2}$ & 1,17 & 20,423 \\
\hline 3 & $\begin{array}{l}\text { Dodecanoic acid, } \\
\text { methyl ester }\end{array}$ & $\mathrm{C}_{13} \mathrm{H}_{26} \mathrm{O}_{2}$ & 31,85 & 25,738 \\
\hline 4 & $\begin{array}{l}\text { Tetradecanoic acid, } \\
\text { methyl ester }\end{array}$ & $\mathrm{C}_{15} \mathrm{H}_{30} \mathrm{O}_{2}$ & 7,45 & 30,343 \\
\hline 5 & $\begin{array}{l}\text { Nonanoic acid, } \\
\text { methyl ester }\end{array}$ & $\mathrm{C}_{10} \mathrm{H}_{20} \mathrm{O}_{2}$ & 37,79 & 34,848 \\
\hline 6 & $\begin{array}{l}\text { Cyclopropanedodeca } \\
\text { noic acid, 2-octyl- } \\
\text { methyl ester }\end{array}$ & $\mathrm{C}_{24} \mathrm{H}_{46} \mathrm{O}_{2}$ & 20,31 & 42,689 \\
\hline
\end{tabular}

\section{CONCLUSIONS}

This work presented production process of biodiesel from the mixtures of waste cooking oil (WCO) and coconut oil (CO) with two step process using acid and base catalyst. The optimum yield observed during this study shows that the $50 \% \mathrm{WCO}$ and $50 \% \mathrm{CO}$ gives the highest yield. The yield obtained was $97.65 \%$. From the analyses based on International standard EN-14214, the biodiesel quality test of this ratio in compliance with EN14214 standards. 


\section{NOMENCLATURE}

$\begin{array}{lll}\text { FFA } & \text { free fatty acid } & \% \\ \mathrm{Na} & \text { Sodium (alkaline metal) } & \mathrm{mg} / \mathrm{Kg} \\ \mathrm{K} & \text { Potassium (alkaline metal) } & \mathrm{mg} / \mathrm{Kg} \\ \mathrm{H}_{2} \mathrm{SO}_{4} & \text { Sulfuric acid } & \mathrm{N} \\ \mathrm{CH}_{3} \mathrm{OH} & \text { methanol } & \% \\ \mathrm{CH}_{3} \mathrm{COOR} & \text { methyl ester } & \% \\ \mathrm{RCOOH} & \text { fatty acid } & \%\end{array}$

Greek letters

$\begin{array}{ll}\text { degree } \\ \rho & \text { density }\end{array}$

$\mathrm{kg} / \mathrm{m}^{3}$

\section{ACKNOWLEDGMENT}

The authors would like to thank Komatsu Biofuel Laboratory PT. Adaro Indonesia, Tanjung, South Kalimantan, for the facilities during the experiments and the Process Technology Laboratory Chemical Engineering Study Program, Engineering Faculty, University of Lambung Mangkurat, South Kalimantan, Indonesia for the facilities during pre-treatment process. We also thanks to Australian National University (ANU) for the 2016/2017 ANU's Research Grant.

\section{REFERENCES}

[1] Gaurav, N., et al., Utilization of bioresources for sustainable biofuels: A Review. Renewable and Sustainable Energy Reviews, 2017. 73: p. 205-214.

[2] de Jong, S., et al., Cost optimization of biofuel production - The impact of scale, integration, transport and supply chain configurations. Applied Energy, 2017. 195: p. 1055-1070.

[3] Azadi, P., et al., The evolution of the biofuel science. Renewable and Sustainable Energy Reviews, 2017. 76: p. 1479-1484.

[4] Golimowski, W., et al., Biofuel parameter dependence on waste fats' fatty acids profile. Fuel, 2017. 197: p. 482-487.

[5] Marchetti, J.M. and A.F. Errazu, Esterification of free fatty acids using sulfuric acid as catalyst in the presence of triglycerides. Biomass and Bioenergy, 2008. 32(9): p. 892-895.
[6] Brito, A., M.E. Borges, and N. Otero, Zeolite Y as a Heterogeneous Catalyst in Biodiesel Fuel Production from Used Vegetable Oil. Energy \& Fuels, 2007. 21(6): p. 3280-3283.

[7] Ayoub, M., et al., Process Optimization for Biodiesel Production from Waste Frying Oil over Montmorillonite Clay K-30. Procedia Engineering, 2016. 148: p. 742-749.

[8] Coconut oil as biofuel, Engineers without borders Australia. 2010 Online]; Available from: https://www.ewb.org.au/.

[9] Chhetri, A., K. Watts, and M. Islam, Waste Cooking Oil as an Alternate Feedstock for Biodiesel Production. Energies, 2008. 1(1): p. 3.

[10] Zappi, M., et al., A Review of The Engineering Aspects of The Biodiesel Industry, M.E.T.R.a.A.L.D. C., Editor. 2003, Swalm School of Chemical Engineering Mississppi University: Mississippi.

[11] Final Report on The Safety Assessment of Oleic Acid, Lauric Acid, Palmitic Acid, Myristic Acid, And Stearic Acid. Journal of the American College of Toxicology, 1987. 6(3).

[12] Banerjee, A. and R. Chakraborty, Parametric sensitivity in transesterification of waste cooking oil for biodiesel production-A review. Resources, Conservation and Recycling, 2009. 53(9): p. 490497.

[13] amgboye, A.I. and A.C. Hansen, Prediction of cetane number of biodiesel fuel from the fatty acid methyl ester (FAME) composition. International Agrophysics, 2008. 22(1): p. 21-29.

[14] Chang, D.Y.Z., et al., Fuel properties and emissions of soybean oil esters as diesel fuel. Journal of the American Oil Chemists' Society, 1996. 73(11): p. 1549-1555.

[15] Hayyan, A., et al., Biodiesel Production from Acidic Crude Palm Oil Using Perchloric Acid. Energy Procedia, 2014. 61: p. 2745-2749.

[16] Wannahari, R., The recovery of used palm cooking oil using bagasse as adsorbent. 2012, Universiti Malaysia Kelantan.

[17] Su, C.-H., Recoverable and reusable hydrochloric acid used as a homogeneous catalyst for biodiesel production. Applied energy, 2013. 104: p. 503-509.

[18] Kumar, V., et al., Physiological, haematological and histopathological responses in common carp (Cyprinus carpio L.) fingerlings fed with differently detoxified Jatropha curcas kernel meal. Food and Chemical Toxicology, 2010. 48(8-9): p. 2063-2072.

[19] Berchmans, H.J. and S. Hirata, Biodiesel production from crude Jatropha curcas $L$. seed oil with a high content of free fatty acids. Bioresource Technology, 2008. 99(6): p. 1716-1721.

[20] Daniyan, I.A., et al., Effects of Reaction Time on Biodiesel Yield. J. of Bioprocessing and Chemical Engineering, 2015. 312. 